\title{
Empathetic-reflective-dialogical re-storying: A teaching-learning strategy for life orientation
}

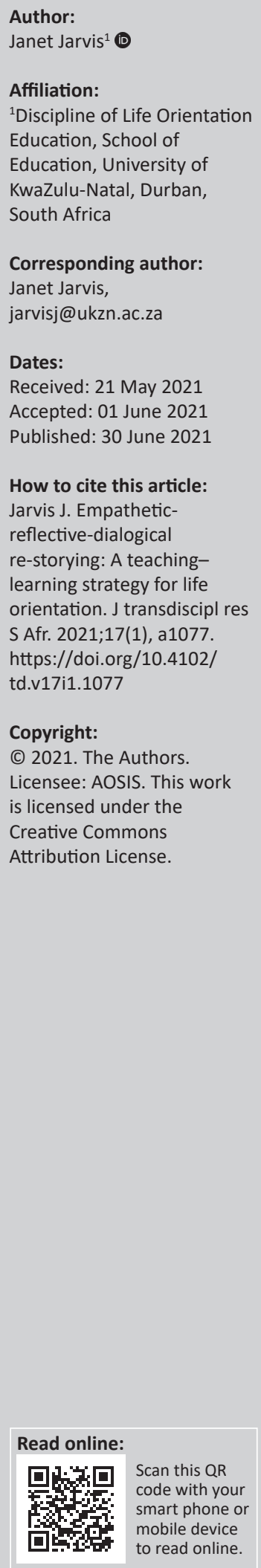

Author:

Education, School of

Education, University of

KwaZulu-Natal, Durban,

South Africa

Janet Jarvis,

Accepted: 01 June 2021

How to cite this article:

Jarvis J. Empathetic-

reflective-dialogical

re-storying: A teachingorientation. J transdiscipl res

S Afr. 2021;17(1), a1077.

https://doi.org/10.4102/

Copyright:

(c) 2021. The Authors.

Licensee: AOSIS. This work

is licensed under the

Creative Commons

Attribution License.

mobile device

to read onlin
This article presents a teaching-learning strategy that has been employed in recent small-scale research projects at a South African higher education institution, and more specifically, in the School of Education. Bachelor of Education Honours students enrolled for a module entitled Contemporary Issues in Life Orientation participated in the studies in 2017 and 2018. The introduction of empathetic-reflective-dialogical re-storying as a teaching-learning strategy created a space for these male and female students to explore their self-dialogue in relation to their understandings and lived experiences of human rights issues, and in this case, gender inequality. This teaching-learning strategy created the opportunity for pre-service teachers to become agents of their own learning as they considered entrenched beliefs and worldviews and co-constructed (re-storied) previously held narratives. By sharing their self-narratives in a community in conversation and then in a community in dialogue with their 'other', the possibility existed for creating new knowledges. This strategy, serving a decolonisation agenda, adopts a transdisciplinary approach. It encourages reflection and reflexivity that can transform technicist classroom practice into potentially transformative classroom praxis.

Keywords: decolonisation; empathetic-reflective-dialogical re-storying; life orientation; transdisciplinarity; classroom praxis.

\section{Introduction}

This article argues for empathetic-reflective-dialogical re-storying ${ }^{1}$ as a teaching-learning strategy employing a transdisciplinary approach. This strategy facilitates an empathetic, reflective, dialogical exploration of human rights issues as they fall within the Life Orientation curriculum. In particular, this article focusses on gender equality as explicitly drawn from this curriculum. An empathetic exploration refers to the capacity to understand and respond to the lived experiences of another person with an increased awareness of that person's thoughts and feelings and that these matters. ${ }^{2}$ Reflection implies thinking through something and not just taking it on face value. This strategy facilitates a reimagining [or re-storying] of current hegemonies that underpin gender inequality. ${ }^{3}$ Re-storying, or reimagining, revising or rewriting or reauthoring an existing narrative, provides the possibility of creating transformed new knowledges. Whilst this strategy is currently employed with pre-service Life Orientation teachers in a higher education institution, it could possibly also be employed in a school context in Life Orientation lessons. This strategy provides a safe space in which these pre-service teachers can consider the way in which their personal identity has been shaped by dominant discourses and how they can impact on their engagement with human rights issues.

This article highlights the right to gender equality, defined as men and women being equal in quality and identical in value or worth, enjoying a shared humanity, with male and female having the same rights and opportunities. ${ }^{4}$ Exploring how a teacher's personal identity shapes his or her gender identity would go part way to perhaps understanding why, in South Africa, gender inequality is still perpetuated after nearly two decades into a new political democratic dispensation, with a well-established constitution and legal system. ${ }^{5}$ Gender identity as used in this article does not refer to sexual orientation. It refers to the way in which, and to what extent, teachers conceptualise their gender identity. Much gender discrimination has been concealed under the guise of cultural and religious tradition with political, religious and cultural leaders defending the origin of specific ritual and practice. Patriarchy is the most important structure supporting male domination. ${ }^{6}$ A substantial study ${ }^{7}$ was conducted with female in-service teachers situated in six schools in four of the nine provinces in South Africa. These schools represented peri-urban and metropolitan contexts and were diverse in terms of cultural, religious and socio-economic circumstances. The findings of this 2013 study showed that teaching-learning about gender equality could be challenging for teachers who have not reflected on their own gender identity 
and how the same is, in many instances, shaped by their religious and cultural discourses. ${ }^{7}$ A recommendation of this 2013 study was that pre-service teachers should be given the opportunity to explore their personal identity. In response to this recommendation, empathetic-reflective-dialogical re-storying has been developed and employed with pre-service teachers in a South African higher education institution. This article makes a methodological contribution, arguing as it does, for the efficacy of this strategy.

\section{Theoretical framework}

Herman's dialogical self theory (DST) conceptualises the dialogical self as a dynamic multiplicity of $I$-positions in the landscape of the mind with differing voices that can engage with one another, with some voices more dominant than others. His theory also provides a link between self and society, ${ }^{8,9}$ advocating that individuals live not only in external spaces but also in the internal space of their society-of-mind. Possible gender identity re-creation can result from the dialogical self in action, ${ }^{10}$ where the individual $I$, positions and his or herself and engages in counter-positioning. An example of this would be when the individual teacher adopts a counter-position to a master narrative, such as that of male dominance, in her society-of-mind. The counter-position adopted in her self-dialogue assists her to move from one position to another in her society-of-mind as a way of gaining an understanding about herself in relation to the world. ${ }^{8}$ Sharing her self-narrative, as informed by her self-dialogue, both with an internal audience (in her 'society-of-mind') and with an external audience, presents the possibility for female teachers to reclaim themselves as they discover the extent to which it is possible to become disentangled from their 'other' (men). Whilst it is recognised that there are more genders than the male and female binary, in the context of this study, 'other' is used by the female pre-service teachers to refer to their male counterparts and vice versa.

Whilst female teachers are made to varying degrees by the master narratives of gender inequality in society, they do have the capacity, to varying degrees, to make themselves. Whilst they are shaped by dominant discourses, they can exercise agency by dis-identifying with and adopting a counter-position to the same. Their gender identity transformation needs to be articulated in their personal, social and professional domains by their resistance to, and challenging of, male hegemony. The following example serves to illustrate this. There are particular discourses in society that do not permit women to have a voice in, for example, religious gatherings. The accompanying dominant discourse creates the I-position in the individual woman's society-of-mind that dictates that ' $I$, as a woman, cannot have a voice in religious gatherings'. Adopting a metaposition $^{11}$ (something of a helicopter view), the individual's self-dialogue, in response to observing and self-reflecting on various $I$-positions including ' $I$, as a mother, can speak up in defence of my children' or ' $I$, as a teacher, can take the lead in an educational setting', reconsiders the position that ' $I$, as a woman, cannot have a voice in religious gatherings'. Her dialogical self in action adopts a counter-position to the dominant discourse in her society-of-mind. She then articulates this by adopting a promoter position ${ }^{11}$ and she voices this counter-position to male dominance, by using her voice in religious gatherings and encouraging other women to do the same.

The individual's ability to adopt this counter-position, to share her self-narrative with an external audience and to take up a promoter position depends on the extent and strength of her gender identity capital. ${ }^{12,13}$ Identity capital refers to the set of strengths individuals have when constructing, framing and presenting their identity in social circumstances. ${ }^{14}$ The accumulation of successful identity exchanges, or social interaction, with their 'other', increases an individual's identity capital. As a female teacher's gender identity capital strengthens, she will be able to voice, both implicitly (in her self-dialogue to an internal audience) and explicitly (to an external audience), and to practise in increasing measure and with increasing confidence, counter-positions to male dominance and gender inequality. By doing so she will also be contributing positively to her professional capital. ${ }^{15}$

\section{Empathetic-reflective-dialogical re-storying}

There is a link between self-narrative and agency. Selfnarrative has a role to play in enabling individuals to discover the degree to which they are entangled with each other and, furthermore, the extent to which it might be possible to become disentangled from each other and thus be freed to build new identities. ${ }^{16}$ It is through considering their selfdialogue and expressing this through self-narratives that information about human rights (human rights literacies) can lead to empathically understanding through human rights (mutual respect) and for human rights (empowering individuals to enjoy and exercise their rights and to respect and uphold the rights of others). ${ }^{17}$ Empathetic-reflectivedialogical re-storying can create a safe space in which preservice teachers can begin to deconstruct master narratives and build both tangible and intangible identity capital before they move into the professional domain. This safe space is not just physical but also figurative.

The strategy comprises five levels. At each level the participants were given questions to consider that were relevant to the research focus (these questions can be found in Tables 1 and 2). At level 1 self-dialogue provides the dynamic flexibility for continued dialogue to an internal audience (the society of mind) and the re-positioning of internal and external positions in the society-of-mind, ${ }^{9}$ and this can lead to external identity stability. At level 2, self-dialogue is expressed through written self-narrative $\mathrm{e}^{18,19}$ to an internal audience, namely the author of the narrative. As they write their own stories, individuals can create an alternative to a master narrative, in this case male hegemony, by undermining and re-interpreting the same..$^{20,21}$ Re-storying takes place as the self-narrative is expressed verbally, in a safe space to an external audience at level 3 , in a community in conversation. ${ }^{22,23}$ In the community in conversation the women and men meet separately to talk, 
TABLE 1: Questions informing the focus on religious identity and gender equality. ${ }^{39}$

\begin{tabular}{|c|c|c|}
\hline $\begin{array}{l}\text { Levels 1-3: Individually and in a Community in } \\
\text { Conversation (men and women separated) }\end{array}$ & Level 4: Community in Dialogue (men and women together) & $\begin{array}{l}\text { Level 5: Community for Transformation (men and } \\
\text { women together) }\end{array}$ \\
\hline Focus: Personal religious identity and gender (in)equality & Dialogue based on the following topics as covered in levels 1-3: & - \\
\hline $\begin{array}{l}\text { - How would you describe your personal religious } \\
\text { identity? } \\
\text { - Gender equality has been defined by Subramanian }{ }^{4} \text { as } \\
\text { female and male being equal to one another in quality } \\
\text { and identical in value with female and male having the } \\
\text { same rights and opportunities. Do you think your } \\
\text { worldview/religious identity affects the way in which } \\
\text { you view the human rights to gender equality? Please } \\
\text { explain. } \\
\text { - What does your religion/worldview say about your } \\
\text { position as a female/as a male? } \\
\text { - What does your religion/worldview say about your role }\end{array}$ & $\begin{array}{l}\text { - Gender-based roles and responsibilities } \\
\text { - Gender-based privileges } \\
\text { - Gender-based expectations of the 'other' } \\
\text { - Religious and/or cultural understandings of the position of } \\
\text { men and women and the possible impact of this on the way in } \\
\text { which gender equality would be approached in professional } \\
\text { spaces, namely the school and more specifically the classroom }\end{array}$ & $\begin{array}{l}\text { - How has empathetic-reflective-dialogical re-storying } \\
\text { impacted your understanding of gender equality in } \\
\text { terms of experiences, roles and responsibilities, } \\
\text { privileges and expectations? } \\
\text { - How has the dialogue impacted on your perspectives } \\
\text { of teaching-learning about gender issues and } \\
\text { promoting gender equality? } \\
\text { - Evaluate the efficacy of empathetic-reflective- } \\
\text { dialogical re-storying for the transformation of } \\
\text { attitudes towards gender (in)equality and for better } \\
\text { understandings of the 'other' in society. }\end{array}$ \\
\hline
\end{tabular}

- What does your religion/worldvie and responsibilities as a female/as a male?

Source: Jarvis J, Mthiyane NP. Conversing at the intersection: Religious identity and the human right to gender equality in a South African teacher education context. Alternation. 2018;23(2018):60-83. https://doi.org/10.29086/2519-5476/2018/sp23a4

TABLE 2: Questions informing the focus on religious identity and the right to bodily self-determination. ${ }^{40}$

\begin{tabular}{|c|c|c|}
\hline $\begin{array}{l}\text { Levels 1-3: Individually and in a Community in } \\
\text { Conversation (men and women separated) }\end{array}$ & Level 4: Community in Dialogue (men and women together) & $\begin{array}{l}\text { Level 5: Community for Transformation } \\
\text { (men and women together) }\end{array}$ \\
\hline $\begin{array}{l}\text { Focus: Personal religious and cultural identity and the right } \\
\text { to bodily self-determination }\end{array}$ & $\begin{array}{l}\text { Discussion based on the following topics as covered in } \\
\text { levels 1-3: }\end{array}$ & - \\
\hline $\begin{array}{l}\text { - How would you describe your personal religious and } \\
\text { cultural identity? } \\
\text { - How does your religious and cultural discourse speak to } \\
\text { the way in which you view the issue of terminating a } \\
\text { pregnancy? } \\
\text { - What do you think are the rights of the female, the male } \\
\text { and the foetus, when it comes to terminating a } \\
\text { pregnancy? }\end{array}$ & $\begin{array}{l}\text { - What do you think are the rights of the female, the male and } \\
\text { the foetus, when it comes to terminating a pregnancy? }\end{array}$ & $\begin{array}{l}\text { - How has your participation in empathetic- } \\
\text { reflective-dialogical re-storying impacted your } \\
\text { understanding of the right to bodily self- } \\
\text { determination, and more specifically the } \\
\text { termination of pregnancy? } \\
\text { - Evaluate the efficacy of empathetic-reflective- } \\
\text { dialogical re-storying for the transformation of } \\
\text { attitudes and for better understanding of your } \\
\text { 'other'. } \\
\text { - How do you think empathetic-reflective-dialogical } \\
\text { re-storying could possibly be an effective strategy } \\
\text { to use in a classroom setting with learners? }\end{array}$ \\
\hline
\end{tabular}

Source: Jarvis J, Mthiyane NP. Exploring religious and cultural identities and the right to bodily self-determination in a South African higher education context. Afr J Gend Relig. 2019;25(1):45-68. https://doi.org/10.14426/ajgr.v25i1.4

providing the opportunity for informal exchange of thoughts and feelings related to lived experiences, in this case, of gender inequality. By doing so the possibility exists for previously held narratives to be re-storied, with the co-production of new knowledges with regard to gender equality. At level 4, a community in dialogue ${ }^{23}$ provides the opportunity for more purposive, discursive exchange as the 'other' dialogues with his or her 'other'. The aim of this dialogue would be to understand self-respect and own positionality and to inspire reciprocal exchanges with tolerant and empathetic understanding. The community in dialogue becomes a community for transformation ${ }^{1}$ at level 5 where both parties, in this case both the men and the women, engage collaboratively to discuss re-storied attitudes that could be transformative for the individual, the classroom and the wider community.

\section{Supporting a decolonisation agenda}

Empathetic-reflective-dialogical re-storying, as a teachinglearning strategy, supports a decolonisation agenda. ${ }^{24}$ Decolonisation in education refers to the process of rethinking, reframing and reconstructing curricula and research that has been the preserve of the Europe-centred, colonial lens. This is a curriculum imperative in higher education in South Africa and as such seeks to change how teaching-learning takes place. Empathetic-reflectivedialogical re-storying specifically supports this decolonisation agenda by encouraging the following: re-searching with participants, empowering students as agents of their own learning, a transdiscipinary approach and challenging, in this case, gender inequality.

\section{Research with participants}

Tibbitts's Activism-Transformation model ${ }^{17}$ is helpful for the understanding of situatedness and the need for teaching and learning methodologies that are participatory, empowering and transformational to be employed. Participants' daily lived experience should be viewed through a human rights lens in order for participants to reflect on their own behaviour and demonstrate new behaviour. Empathetic-reflectivedialogical re-storying contributes to this process, adopting as it does, a bottom-up approach.

In a Western research methodological stance research is performed to, on or about participants. Decolonial research makes the shift to research that is carried out with the participants. Pre-service teachers are re-positioned from objects of research to co-researchers as they engage in selfreflection and self-dialogue. In a community in conversation and in a community in dialogue the potential exists for re-storying to take place as new interpretations and understandings speak to lived experience ${ }^{25}$ and infuse dominant discourses.

In contrast to the typically Western ideology of individual or focus group interviews, ${ }^{26}$ this strategy, akin to Chilisa's Talking Circle[s], ${ }^{27}$ attempts to engage in research in a community in conversation, community in dialogue and community for transformation. An opportunity is created for participants to engage with and seek to know their 'other' in a research context, which is safe and in which they are coresearchers. 


\section{Empowering students as agents of their own learning}

Empathetic-reflective-dialogical re-storying empowers pre-service Life Orientation teachers to be agents of their own learning as they consider dominant narratives and take responsibility for the generation of new knowledges by co-constructing (re-storying) new understandings thereof. ${ }^{3}$ It is in the community in conversation, in particular, that they strengthen their identity capital ${ }^{12,14}$ and are empowered to engage with their 'other' in a community in dialogue. As they participate in a community for transformation, together with their 'other', the potential exists for them to become agents of transformation and change.

\section{Transdisciplinarity}

Historically, the colonial legacy is that of discreet disciplines operating in isolation from one another. Empatheticreflective-dialogical re-storying adopts a transdisciplinary approach, ${ }^{1}$ where transdisciplinary boundary talk takes place in the blurring of boundaries between both discreet disciplines and integrated fields of knowledge. Engagement with human rights issues, such as that of gender equality, takes place in the space between, across and beyond academic disciplines. ${ }^{28,29,30}$ Pre-service teachers meet in the included middle $^{31}$ when they co-construct their stories. By doing so they are empowered to build identity capital. ${ }^{12,14}$ This can be emancipatory and empowering.

\section{Challenging gender inequalities}

Challenging male hegemony plays a substantive role in decolonisation. ${ }^{32}$ Gender ideologies in which social relations between women and men are defined become stubbornly defended as traditional and immutable. ${ }^{4}$ Empatheticreflective-dialogical re-storying provides an opportunity for women (and also men) to explore gender inequalities and to dis-identify with the same, in a safe space in a community in conversation and then in a community in dialogue.

\section{Methodology: Two recent small- scale research projects}

The research took place within a feminist paradigm. Feminist research actively seeks to remove the power imbalance between the researcher and the participant as it seeks to address social inequality. It also begins with the standpoints and experiences of women. Feminist research, whilst addressing the assumption that there are structural gender inequalities, seeks to deconstruct commonly held discourses. Unequal power relations existing as a result of gender inequality and the way in which women are represented and positioned in society are addressed.

Narrative inquiry as a methodology within narrative research ${ }^{33,34,35}$ and with a strong representation in the field of education $^{36}$ promotes authentic accounts of lived experiences. ${ }^{37}$ In the case of both these small-scale projects, narratives were explored, which are socially constructed, interpreted and reinterpreted, giving meaning to the participant's lived experiences of gender inequality. A safe space $^{23}$ was created to provide the opportunity to hear the participant's voices in response to the master narrative of patriarchy. It was the place where the participants could feel sufficiently secure to unburden themselves. ${ }^{38}$ The potential existed for these narratives to have an emancipatory function, transforming individual lives and the broader culture. The participants submitted their written self-narratives to the researcher and the narratives at levels 4 and 5 were audiorecorded. The latter were later transcribed for the purposes of analysis.

In both small-scale projects participants signed consent forms and were assured that their anonymity would be protected and that pseudonyms would be used when citing their responses. The ethical code of conduct and the requirements set for narrative research by the tertiary institution's ethics committee were adhered to for both projects. The participants in both projects included both male and female pre-service teachers, and they all happened to be Black African ranging in age from their mid-20s to 50s. In both cases they were registered for a Bachelor of Education Honours degree and more specifically a module called Contemporary Issues in Life Orientation. In this Life Orientation module, whilst learning about empathetic-reflective-dialogical re-storying as a teaching-learning strategy, the pre-service teachers simultaneously became participants in applying the same as a research methodology.

In the first project ${ }^{39} 24$ students agreed to participate and engage with the human rights to gender equality. In the second cohort 39 participants engaged with the human rights to bodily self-determination and, more specifically, the termination of pregnancy. ${ }^{40}$

Tables 1 and 2 show the questions that informed the engagement at the various levels in each small-scale project.

Participants expressed the opinion that empathetic-reflectivedialogical re-storying provided the opportunity for them to consider their self-dialogue (level 1) and to reflect on their personal identity. They were sensitised to the possibilities of their dialogical self in action as they adopted meta positions and then counter-positions to the dominant voices as evidenced in their society-of-mind. ${ }^{9}$ The men and women met separately at level 3, the community in conversation, so as to provide a safe space in which to share their self-narratives. At levels 4 and 5, the community in dialogue and the community for transformation, they met together. In the community for transformation the participants reflected that they became far more aware that their self-dialogue impacts their selfnarratives (level 2). They articulated the view that by participating in empathetic-reflective-dialogical re-storying they troubled master narratives and mostly re-storied understandings of gender equality and also the right to bodily self-determination. 


\section{Findings}

One of the male participants said that he found the community in conversation (level 3) revealing as men spoke to men about their 'other' (women). He said that he found it:

'... very impactful ... I thought I understood gender equality, but in community in conversation made aware of our privileges as men ... we have a lot of privileges we are not aware of.' (Dumi, male, 2017)

The female participants, in particular, commented that the community in dialogue (level 4) was most helpful providing as it did, the opportunity for them to express their perspectives about their 'other' (men) to their 'other' (men). Their successful exchanges with their 'other' strengthened their gender identity capital and opened up a space for constructing a narrative in which they can be agents of change, directing future-oriented action:

'I think this strategy gives out many possible ideas to think critically ... what can we do ... what are the gaps ... what can be changed.' (Phumi, female, 2017)

'This strategy is transformative ... some will actually go home today and some have daughters and some have sons and will try and change things.' (Ncami, female, 2017)

Faced with pregnancy, women often struggle 'alone'. They are made to feel judged, embarrassed, guilty and shameful about the decision they have made to end a pregnancy ${ }^{41}$ :

'I feel and know that some parents (especially in our African culture or religion) if they know that you are pregnant can even chase you away from home. There is no space to discuss what you are going through and how and why you are pregnant, let alone what impact in your personal life can this said pregnancy do to "you" as a person not the wider community. Therefore, I think sometimes decisions are taken as one is forced by circumstances ....' (Lungi, female, 2018)

As the female participants engaged in their community in conversation (level 3), the identity capital of individual women increased as they drew on the tangible asset of their membership of a social group of women with whom they could share their self-narrative of their lived experience. This became clear when they addressed their male counterparts at level 4 with confidence, resolution and conviction.

The community in dialogue provided the opportunity for the female participants to dialogue with their 'other' (men). The accumulation of successful dialogical exchanges increased their identity capital. They said that they were empowered as they gained confidence by voicing their opinions and sharing their lived experiences in a context in which they did not feel judged:

'I must say that the strategy is therapeutic. One learns to get the perspectives of others and realise that I am not alone, I can survive. If what I do is a sin, then I will go to church, apologise to God, and move on with my life because if there is no support, I have to find ways so that I do not bring a child in this world who is going to suffer.' (Agnes, female, 2018)
The community for transformation (level 5), in both smallscale projects, provided the opportunity for the participants to think critically about the processes of socialisation and to discuss and begin the process of deconstructing the same. Whilst the participants were aware of the influence of master narratives and also how their particular contexts can shape their behaviour, engaging in this teaching-learning strategy assisted them to see that they can be agents of change. The strategy opened up a space for constructing a narrative in which they have some ability to direct future-oriented action. Their views pertaining to the efficacy of empatheticreflective-dialogical re-storying included the following:

'I found this strategy to be helpful especially in levels 1 and 2 where one had to listen to different voices before one takes a decision ... it gives you possible ideas to question yourself to say: What can you change? How can you do that? Why should you act in that particular way?' (Sipho, male, 2017)

'The methodology allows you, and especially us as males, to understand the female side of the story. At the same time, it allows every one of us time with yourself, and discussions allow you to make a choice to change or not to change your attitude.' (Spha, male, 2017)

'... this strategy stimulated the mind, gives us many possibilities and ideas leading to critical thinking and to question yourself for better understanding and the probing questions assisted ... it has a potential to be transformative.' (Thabi, female, 2017)

'The strategy transforms the way you perceive issues and other people. We need to go out there as changed men and women so that we will be transformed parents to our children.' (Andile, male, 2017)

'I think that this methodology is helpful, constructive and transformative in that it gives you an opportunity to sit back and self-reflect on the topic and further gives you a particular worldview to think about other people as well and understand their actions.' (Nonjabulo, male, 2018)

'It teaches us not to be judgemental, whether female or male.' (Bongi, female, 2018)

'The strategy allows people to open up, share with one another, and the goal is to learn and acquire new knowledge ... one's story can help or groom somebody and my story can also groom the 'other' ... I think these dialogues should happen in wider communities as well as in the wider university community ... for other students to benefit as well.' (Maureen, female, 2018)

Participants in both small-scale projects were of the opinion that this strategy could be an effective tool to employ in their professional space to enhance teacher-learner relationships. Their views can be summed up by what Bongi had to say:

'As teachers, we need to do what is just with our learners ... social justice.... We need to teach them and expose them to such [human rights] issues.' (Bongi, female, 2017)

We need teachers who will not place gendered expectations on their learners ${ }^{42,43}$ either overtly or through the hidden curriculum $^{44}$ of gender differentiation, which is provided by stereotypes. The hidden curriculum refers to the transmission of norms, values and beliefs that are the side effect of schooling. For example, a teacher may teach about gender equality in the classroom, and yet practice gender inequality 
when certain tasks are assigned gender-specifically, thereby teaching that there are specific tasks that should be assigned to boys and others to girls. An example would be when girls only are always expected to clean the classroom or comments are made by the teacher that only boys can do mathematics.

We need teachers, both male and female, who are able to voice explicitly and practise a counter-position to male hegemony, by treating the female and male learners equally and by addressing any form of gender abuse, be it verbal or physical. Both female and male learners should be encouraged to engage critically with issues of gender equality, not only within the classroom but also within their personal and social domains. A teacher who has experienced gender identity transformation can encourage his or her learners to be not only reflective in their practice, but also reflexive, where the practical implications for possible change are considered, to inform new attitudes and practices. This approach could transform classroom practice into classroom praxis. ${ }^{45,46}$

\section{Conclusion}

This article has argued for the inclusion of empatheticreflective-dialogical re-storying as a teaching-learning strategy that can be used in life orientation. This strategy provides the opportunity for currently held narratives of the lived experience of, in this case, gender inequality, to be dialogically explored. This dialogical exploration takes place in the dialogical self and in dialogue with the 'other'. It is important to provide the opportunity for pre-service teachers to consider their self-dialogue and to engage their dialogical self in action, by adopting in their society of mind, counterposition s to master narratives that perpetuate inequalities. The strength and extent of an individual's identity capital enable the possible re-storying of previously held narratives, in this case, of male hegemony. Empathetic-reflectivedialogical re-storying also serves in decolonising the curriculum, promoting as it does a transdisciplinary approach that changes how teaching-learning takes place and empowering students as agents of their own learning as they becoming co-researchers. By engaging in self-reflection and empathetically dialoguing human rights issues in the classroom, teachers have the potential to go beyond mere technicist classroom practice. They are equipped to facilitate classroom praxis that is empathetic and both reflective and reflexive. This has the potential to possibly be transformative for learners in the classroom, as future participating citizens in the greater South African society.

\section{Acknowledgements Competing interests}

The author declares that she has no financial or personal relationship that may have inappropriately influenced her in writing this article.

\section{Author's contributions}

J.J. declares that she the sole author of this research article.

\section{Ethical considerations}

Full approval for a period of 3 years was given by the University of KwaZulu-Natal, College of Humanities, Humanities and Social Sciences Research Ethics Committee (HSS/0297/017) for research to be undertaken with consenting students in the area of Human Rights/and religious identity.

\section{Funding information}

This research received no specific grant from any funding agency in the public, commercial or non-profit sectors.

\section{Data availability}

The authors confirm that the data supporting the findings of this study are available within the article.

\section{Disclaimer}

The views and opinions expressed in this article are those of the author and do not necessarily reflect the official policy or position of any affiliated agency of the author.

\section{References}

1. Jarvis J. Re-storying for transdisciplinarity: A proposed teaching-learning strategy in a context of human rights education. J Transdisciplinary Res. 2018;14(2):a483. https://doi.org/10.4102/td.v14i2.483

2. Barton $\mathrm{G}$, Garvis $\mathrm{S}$. Theorizing compassion and empathy in educational contexts. What are compassion and empathy and why are they important? In: Barton G, Garvis S, editors. Compassion and empathy in educational contexts. Cham: Palgrave MacMillan, 2019; p. 3-14.

3. Council for Higher Education. Decolonising the curriculum: Stimulating debate. Pretoria: Council for Higher Education, 2017; p. 1-12.

4. Subrahmanian R. Gender equality in education: Definitions and measurement. Int J Educ Dev. 2005;25(4):395-407. https://doi.org/10.1016/j.ijedudev.2005.04.003

5. Jarvis J. Reflections on gender identity in a safe space for transforming classroom praxis. J Stud Relig. 2014;27(1):169-191.

6. Measor L, Sikes P. Gender and schools. London: Cassell; 1992.

7. Jarvis J. Female teachers' religious and cultural identities and gender equality. Unpublished doctoral thesis. Potchefstroom: North West University; 2013.

8. Hermans H, Hermans-Konopka A. Dialogical self theory: Positioning and counterpositioning in a globalizing society. Cambridge: Cambridge University Press; 2010.

9. Hermans $\mathrm{H}$. The dialogical self: A process of positioning in space and time. In: Gallagher S, editor. The Oxford handbook of the self. Oxford: Oxford University Press, 2011; p. 652-678.

10. Hermans $\mathrm{H}$, Dimaggio G. Self, identity, and globalization in times of uncertainty: A dialogical analysis. Am Psychol Assoc. 2007;11(1):31-61. https://doi. org/10.1037/1089-2680.11.1.31

11. Meijers $\mathrm{F}$, Hermans $\mathrm{H}$. Dialogical self theory in education: An introduction. In: Meijers $F$, Hermans $H$, editors. The dialogical self theory in education. Cham: Springer, 2018; p. 1-18.

12. Côté J. Sociological perspectives on identity formation: The culture-identity link and identity capital. J Adolesc. 1996;19(5):417-428. https://doi.org/10.1006/ jado.1996.0040

13. Côté J. Identity capital, social capital and the wider benefits of learning: Generating resources facilitative of social cohesion. J Adolesc. 2005;20(5):577-597. https:// doi.org/10.1006/jado.1997.0111

14. Côté J, Levine C. Identity formation, agency and culture: A social psychological synthesis. Mahwah, NJ: Lawrence Erlbaum Associates Publishing; 2002.

15. Hargreaves A, Fullan, M. Professional capital: Transforming teaching in every school. New York, NY: Teachers College Press; 2012.

16. Nuttall S. Entanglement: Literary and cultural reflections on post-apartheid Witwatersrand: Wits University Press; 2009.

17. Tibbitts F. Evolution of human rights education models. In: Bajaj M, editor. Human rights education: Theory, research, praxis. Pennsylvania, PA: University of Pennsylvania Press, 2017; p. 69-95.

18. McAdams D. Narrative Identity. In: Schwartz S, Luyckx K, Vignoles V, editors. Handbook of identity theory and research. New York, NY: Springer, 2011; p. 99-116.

19. Riessman CK. Narrative methods for the human sciences. Los Angeles, CA: Sage; 2008. 
20. Tsang T. Let me tell you a story: A narrative exploration of identity in high performance sport. Sociol Sport J. 2000;17(1):44-59. https://doi.org/10.1123/ ssj.17.1.44

21. Lawler S. Identity: Sociological perspectives. Cambridge: Polity Press; 2008.

22. De Wet A, Parker G. Communities in conversation: Opportunities for women and girls' self-empowerment. Gend Dev. 2014;22(1):109-125. https://doi.org/10.108 $0 / 13552074.2014 .889341$

23. Roux C. A social justice and human rights education project: A search for caring and safe spaces. In: Roux C, editor. Safe spaces: Human rights education in diverse contexts. Rotterdam: Sense Publishers; 2012.

24. Jarvis J. Empathetic-reflective-dialogical re-storying for decolonisation: An emancipatory teaching-learning strategy for religion education. Br J Relig Educ. 2020;43(1):68-79. https://doi.org/10.1080/01416200.2020.1831439

25. McCormack C, Kennelly R. 'We must get together and really talk...'. Connection, engagement and safety sustain learning and teaching conversation communities. Reflective Practice. 2011;12(4):515-531. https://doi.org/10.1080/14623943.2011. 590342

26. Tuhiwai SL. Decolonizing methodologies. Bloomsbury: Zed Books; 2012.

27. Chilisa B. Indigenous research methodologies. Thousand Oaks, CA: Sage; 2012.

28. McGregor SLT, Volckmann, R. Transversity: Transdisciplinarity in higher education. In: Hampson $G$, ih-Tolsma $M$, editor. Leading transformative higher education. Olomouc: Palacky University Press, 2013; p. 58-81.

29. Nicolescu B. Towards transdisciplinary education. J Transdisc Res South Af 2005;1(1):5-16. https://doi.org/10.4102/td.v1i1.300

30. Nicolescu B. Methodology of transdisciplinarity. World Futures. 2014;70(3-4): 189-199. https://doi.org/10.1080/02604027.2014.934631

31. Nicolescu B. Transdisciplinarity and sustainability. Austin, TX: The Atlas Publishing; 2012.

32. Ndlovu-Gatsheni SJ. Why are South African universities sites of struggles today? Johannesburg: JoburgPost Online; 2016.

33. Chase S. Narrative inquiry: Multiple lenses, approaches, voices. In: Denzin N, Lincoln Y, editors. The Sage handbook of qualitative research. Thousand Oaks, CA Sage Publications, 2005. p. 651-679.
34. Clandinin DJ, Murphy MS, Huber J, Orr AM. Negotiating narrative inquiries: Living in a tension-filled midst. J Educ Res. 2010;103(2):81-90. https://doi. org/10.1080/00220670903323404

35. Luttrell W. Qualitative educational research. New York, NY: Routledge; 2010.

36. Clandinin DJ. Handbook of narrative inquiry: Mapping a methodology. Thousand Oaks, CA: Sage; 2007.

37. Nothling M. Telling our stories - Feeling our pain: Designing a transformational human rights course. In: Swanepoel F, editor. Religion and morality transformation. Pretoria: University of South Africa Press, 2001; p. 134-168.

38. Jansen J. Image-ining teachers: Policy images and teacher identity in South African classrooms. S Afr J Educ. 2001;21(4):242-246.

39. Jarvis J, Mthiyane NP. Conversing at the intersection: Religious identity and the human right to gender equality in a South African teacher education context. Alternation. 2018;23(2018):60-83. https://doi.org/10.29086/2519-5476/2018/ sp23a4

40. Jarvis J, Mthiyane NP. Exploring religious and cultural identities and the right to bodily self-determination in a South African higher education context. Afr J Gend Relig. 2019;25(1):45-68. https://doi.org/10.14426/ajgr.v25i1.4

41. Beynon-Jones SM, Toerien MG, Macleod C. Articulating reproductive justice through reparative justice: Case studies of abortion in Great Britain and South Africa. Cult Health Sex. 2017;19(5):601-615. https://doi.org/10.1080/1369105 8.2016 .1257738

42. Korkmaz I. Teachers' opinions about the responsibilities of parents, schools and teachers in enhancing student learning. Education. 2007;127(3):389-399.

43. Lindley $H$, Keithley M. Gender expectations and student achievement. Roeper Rev. 1991;13(4):213-215. https://doi.org/10.1080/02783199109553361

44. Boostrom R. Hidden curriculum. In: Kridel C, editor. Encyclopedia of curriculum studies 2. Thousand Oaks, CA: Sage, 2010; p. 440

45. Roux C, Du Preez P. Clarifying students' perceptions of different belief systems and values: Prerequisite for effective education praxis. S Afr J Higher Educ. 2006;30(2):514-531

46. Quinlan O. The thinking teacher. Carmarthen: Independent Thinking Press; 2014. 